\title{
Obituary: A Remembrance of Nas S. Eftekhar (1935-2016)
}

\author{
William Macaulay MD
}

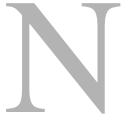

as S. Eftekhar MD, former member of The Association of Bone and Joint Surgeons ${ }^{\circledR}$ (ABJS), passed away on November 14, 2016 in Los Angeles, CA, USA. He was 81 years old.

Dr. Eftekhar (Fig. 1) is widely recognized for designing the first TKA implants that included a short-stemmed, metal-backed tibial component (Mark I and Mark II), and for introducing the concept of modularity in knee implant design [1].

Dr. Eftekhar established the total hip and knee replacement program at Columbia-Presbyterian

Hospital, which specialized in low-friction

\footnotetext{
The author certifies that neither he, nor any members of his immediate family, have any commercial associations (such as consultancies, stock ownership, equity interest, patent/licensing arrangements, etc) that might pose a conflict of interest in connection with the submitted article. The opinions expressed are those of the writers, and do not reflect the opinion or policy of $C O R R^{\circledR}$ or The Association of Bone and Joint Surgeons ${ }^{\mathbb{R}}$.
}

W. Macaulay MD ( $\square)$

Department of Orthopaedic Surgery, NYU Langone Medical Center/Hospital for Joint Diseases, 246 East 20th Street, Suite 103, New York, NY 10003, USA e-mail: william.macaulay@nyumc.org arthroplasty. In 1969, he performed the first total knee replacement in the United States at Columbia-Presbyterian Hospital [8]. In his nearly 30-year career as Clinical Professor of Orthopaedic Surgery at New York Presbyterian/Columbia University Medical Center, Dr. Eftekhar performed more than 4000 total hip and knee replacements [4].

A protégé of the renowned orthopaedic surgeon Sir John Charnley, Dr. Eftekhar's steadfast adherence to Sir Charnley's low-friction principles stemmed from his 18-month training at the famed Wrightington Hospital in Wigan, England beginning in October 1967. At that time, infection was a major problem for Sir Charnley's lowfrictional torque arthroplasty. In order to prevent infection, Sir Charnley and his team experimented with using body exhaust suits during surgery. Dr. Eftekhar studied the permeability of surgical gowns, and his findings remain an exhibit in the Hip Center at Wrightington Hospital today.

"Dr. Eftekhar and other Fellows working with Sir Charnley in those early years of hip replacement set a very high standard of surgery, research, and development," B. Michael Wroblewski MB ChB, FRCS (Ed), MSc (Mech Eng), Director of the
Charnley Research Institute at Wrightington Hospital told $C O R R^{\circledR}$.

The Charnley Research Institute records show that from October 1967 to November 1968, Dr. Eftekhar performed 95 primary low-friction arthroplasties (including three conversions from intertrochanteric osteotomy and two from hip fusions) and one revision late in his stay.

A technically gifted surgeon, Dr. Eftekhar would not accept anything less than perfection.

"I have never met another hip surgeon who more often achieved the preoperative plan that he set out to accomplish during surgery," Richard Iorio MD, Professor of Orthopaedic Surgery at New York University Langone Medical Center and the Hospital for Joint Diseases told $C_{O R R^{\circledR}}$. "During his Charnley low friction arthroplasty, he would perfectly juxtapose the cut greater trochanteric surfaces with an impeccable wiring technique."

His pursuit of perfection likely earned him a new job. By chance, Dr. Frank Stinchfield, the Chairman of the Orthopaedic Department at ColumbiaPresbyterian Medical Center at the time, observed Dr. Eftekhar performing a total hip replacement at Wrightington and soon invited him to 


\section{Obituary}

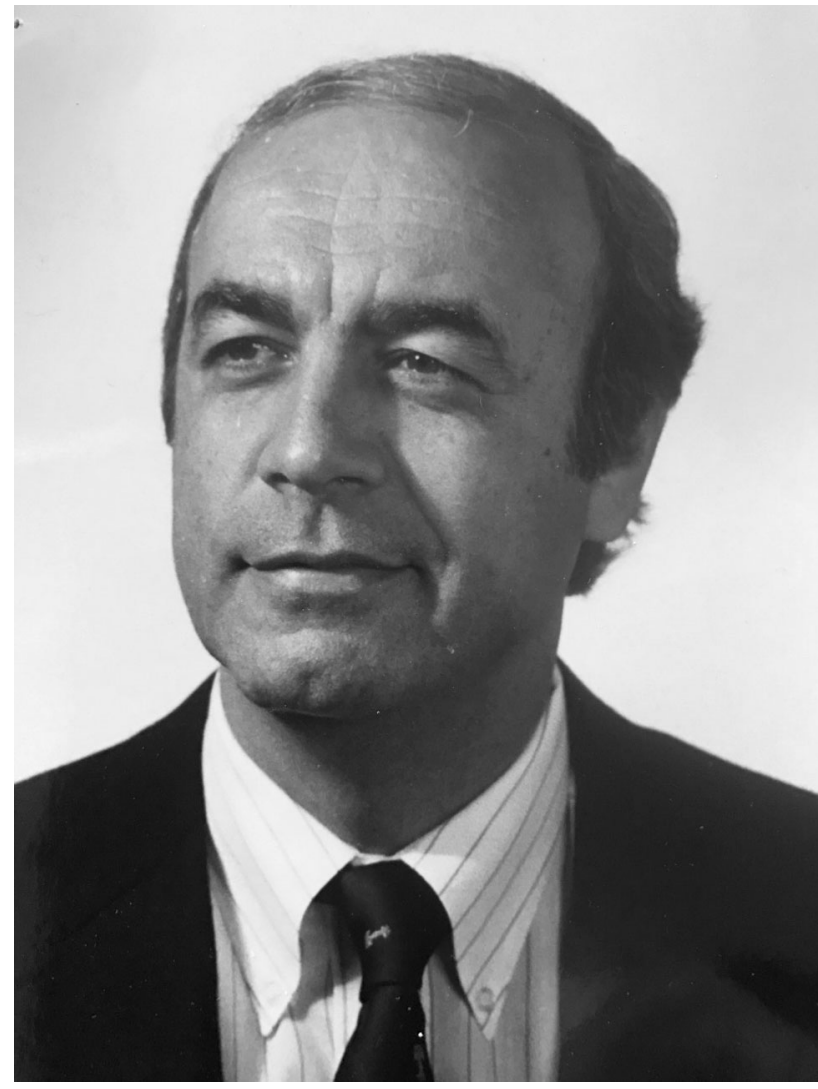

Fig. 1 Nas S. Eftekhar MD.

join his faculty in New York. Dr. 1986 told $\operatorname{CORR}^{\circledR}$ that he always Eftekhar stayed for nearly 30 years.

Beyond his surgical prowess, Dr. Eftekhar was an innovator, developing and holding patents on the Mark I (1969) and Mark II (1973) total knee replacements. Ronald P. Grelsamer MD, Dr. Eftekhar's fellow in 1985respected Dr. Eftekhar's admirable quest for the truth.

"He was under incredible pressure from industry to market his Mark I total knee design and also a monoblock femoral stem for use in total hips (with an offset $22 \mathrm{~mm}$ ball); he resisted bringing these products to market unless they had 10 to 15 years of excellent results," Dr. Grelsamer said. "He clearly was not very interested in the money that could have resulted from those marketing endeavors."

Indeed, Dr. Eftekhar's focus remained on the patient. In his book, Principles of Total Hip Arthroplasty, Dr. Eftekhar wrote, "Not the hip; the patient is considered first, and the hip is reconstructed by individualizing the clinical problem based on anatomical and pathological findings" [3].

Dr. Eftekhar was also interested in mentoring the top orthopaedic surgeons and medical trainees from across the globe in low-friction arthroplasty. Seneki Kobayashi MD, PhD, Vice President, Suwa Red Cross Hospital, studied alongside Dr. Eftekhar at Columbia University Medical Center from July 1991 to September 1992. They collaborated on a 10- to 20-year followup of clinical and radiological studies that revealed the risk factors affecting fixation failure of primary Charnley low-friction arthroplasty [6, 7]. During that period, Dr. Kobayashi and Dr. Eftekhar lived in the same neighborhood in New Jersey. Dr. Eftekhar would give Dr. Kobayashi a ride to Columbia-Presbyterian Medical Center every day, chatting as they crossed the George Washington Bridge into Manhattan. 


\section{Obituary}

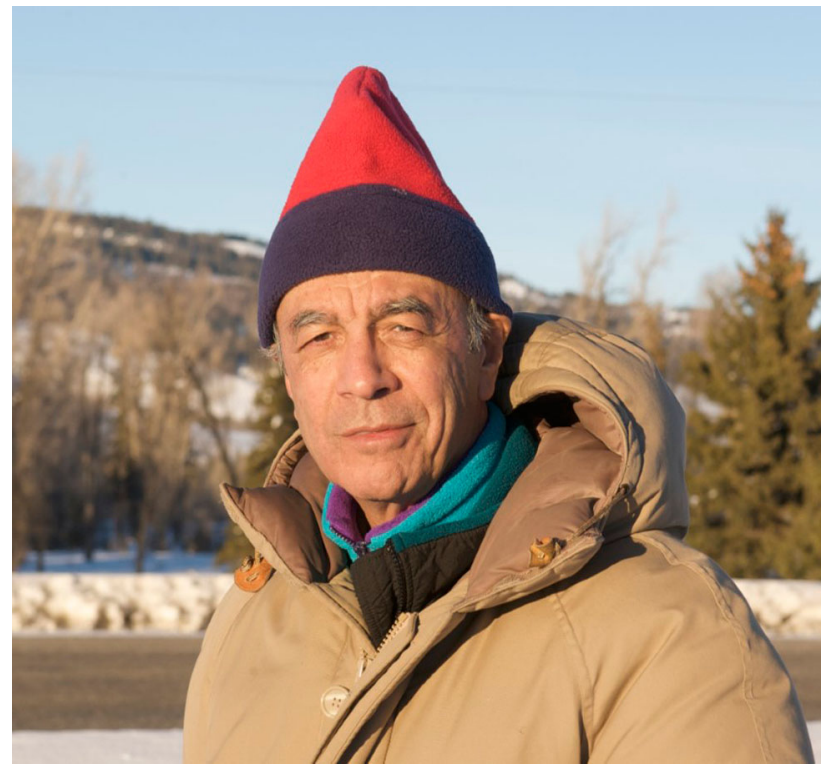

Fig. 2 Dr. Eftekhar was a natural athlete who trekked the thin-aired portions of both Mt. Everest and Mt. Kilimanjaro. (Published with permission from Barbara Eftekhar).

"He is still alive in my memory, vividly talking to me about THA, Sir John Charnley, and other things," Dr. Kobayashi recalled. "I appreciate Dr. Eftekhar for giving me an opportunity to study with the man who studied and developed THA with Sir John Charnley; who trained and educated many young doctors; and who successfully treated numerous patients with disabling hip pain both directly and indirectly, and educated hip surgeons with his lectures, published papers, and books."

Dr. Eftekhar authored Total Hip Arthroplasty [5] in 1993, a seminal work in two volumes that still serves as an important learning tool for hip surgeons and those in residency.

"The book includes his guiding principles, techniques, and the philosophies required for THA," Dr. Kobayashi said. "A career literary masterpiece."
Outside of orthopaedics, Dr. Eftekhar was an accomplished photographer (thanks to his brother who gave him his first camera in 1952), a world traveler, having visited 50 countries on all seven continents, and a natural athlete who trekked the thin-aired portions of both Mt. Everest and Mt. Kilimanjaro (Fig. 2).

In 2011, having always been fascinated with patterns, Dr. Eftekhar published The Visual Language of Patterns: Decoding Infinite Natural and Man-Made Worlds [2]. In close collaboration with his wife Barbara, as text editor and his daughter, Kimberly, as creative and production design manager, his book features artistic photos from his world travels (Fig. 3).

Shortly after I joined Columbia Orthopaedics in 1999, Dr. Eftekhar told me about how his career-long association with ABJS and $C O R R^{\mathbb{R}}$ was "close to his heart." $\mathrm{He}$ mentioned that it was at the familyoriented annual meetings of the ABJS that he and his wife Barbara made lifelong friendships.

Dr. Eftekhar was a renaissance man-a dedicated family man, scientist, physician, and surgeon of the highest integrity. I feel fortunate to have sat in the Endowed Chair at Columbia University from 2007 to the 


\section{Obituary}

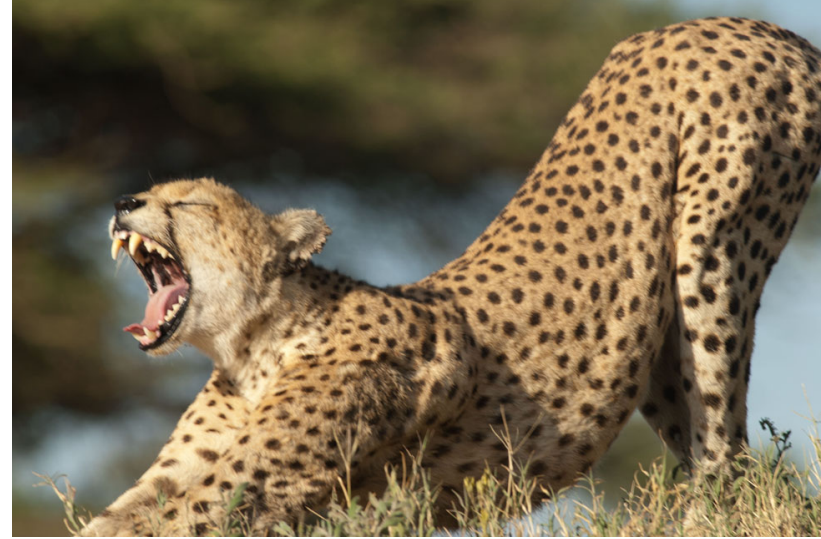

Fig. 3 Dr. Eftekhar's photo of a cheetah stretching in Ngorongoro Crater, Tanzania graces the cover of his book, The Visual Language of Patterns: Decoding Infinite Natural and ManMade Worlds [2]. (Photo credit: Nas. S. Eftekar MD. Published with permission from Barbara Eftekhar).

end of 2016, which resulted from philanthropy provided by Dr. Eftekhar's former patient, Mrs. Anne Youle Stein. This Endowed Chair eventually became the Nas S. Eftekhar Professorship in 2011.

Dr. Eftekhar is survived by his loving wife, Barbara Eftekhar, his daughter, Kimberly Eftekhar, his son, Kirt Eftekhar and his daughter-in-law, Valerie Schadt, his grandsons, Westley and Rylan Eftekhar and his sister-inlaw, Catherine Pastore.

\section{References}

1. Bonnin M, Amendola NA, Bellemans J, MacDonald SJ, Menetrey J, eds. The Knee Joint: Surgical Techniques and Strategies. Paris, France; Springer-Verlag: 2012.

2. Eftekhar NS. A Visual Language of Patterns: Decoding Infinite Natural and Man-Made Worlds. Los Angeles, CA: Eftekhar Photography LLC; 2011.

3. Eftekhar NS. Principles of Total Hip Replacement. St. Louis, MO: CV Mosby; 1978.

4. Eftekhar NS. The classic: Dislocation and instability complicating low friction arthroplasty of the hip joint. Clin Orthop Relat Res. 2006;453: 1-6.

5. Eftekhar NS. Total Hip Arthroplasty. St. Louis, MO: CV Mosby; 1993.

6. Kobayashi S, Eftekhar NS, Terayama K. Predisposing factors in fixation failure of femoral prostheses following primary Charnley low friction arthroplasty: A 10- to 20-year followup study. Clin Orthop Relat Res. 1994;306:73-83.

7. Kobayashi S, Eftekhar NS, Terayama $\mathrm{K}$, Iorio R. Risk factors affecting radiological failure of the socket in primary Charnley low friction arthroplasty: A 10- to 20-year followup study. Clin Orthop Relat Res. 1994;306:84-96.

8. Robinson RP. The early innovators of today's resurfacing condylar knees. $J$ Arthroplasty. 2005;20:2-26. 